\title{
Thomas Wolsey on stage and screen
}

\begin{tabular}{|c|c|}
\hline \multicolumn{2}{|c|}{$\begin{array}{l}\text { Author: } \\
\text { Patrick Hornbeck }\end{array}$} \\
\hline \multicolumn{2}{|c|}{$\begin{array}{l}\text { Affiliations: } \\
{ }^{1} \text { Department of Theology, } \\
\text { Fordham University, USA }\end{array}$} \\
\hline \multicolumn{2}{|c|}{$\begin{array}{l}{ }^{2} \text { Faculty of Theology, } \\
\text { University of Pretoria, } \\
\text { South Africa }\end{array}$} \\
\hline \multicolumn{2}{|c|}{$\begin{array}{l}\text { Project leader: J. Buitendag } \\
\text { Project number: } 02402343\end{array}$} \\
\hline \multicolumn{2}{|c|}{$\begin{array}{l}\text { Description: } \\
\text { Prof. Dr Hornbeck is } \\
\text { participating in the research } \\
\text { project, 'Theology and } \\
\text { Nature', directed by } \\
\text { Prof. Dr Johan Buitendag, } \\
\text { Department of Dogmatics } \\
\text { and Christian Ethics, Faculty } \\
\text { of Theology, University of } \\
\text { Pretoria and Dean of the } \\
\text { Faculty of Theology. }\end{array}$} \\
\hline \multicolumn{2}{|c|}{$\begin{array}{l}\text { Corresponding author: } \\
\text { Patrick Hornbeck, } \\
\text { hornbeck@fordham.edu }\end{array}$} \\
\hline \multicolumn{2}{|c|}{$\begin{array}{l}\text { Dates: } \\
\text { Received: } 10 \text { Dec. } 2015 \\
\text { Accepted: } 21 \text { Mar. } 2016 \\
\text { Published: } 19 \text { Aug. } 2016\end{array}$} \\
\hline \multicolumn{2}{|c|}{$\begin{array}{l}\text { How to cite this article: } \\
\text { Hornbeck, P., 2016, 'Thomas } \\
\text { Wolsey on stage and screen', } \\
\text { HTS Teologiese Studies/ } \\
\text { Theological Studies } 72(4) \text {, } \\
\text { a3285. http://dx.doi. } \\
\text { org/10.4102/hts.v72i4.3285 }\end{array}$} \\
\hline \multicolumn{2}{|c|}{$\begin{array}{l}\text { Copyright: } \\
\text { (C) 2016. The Authors. } \\
\text { Licensee: AOSIS. This } \\
\text { is licensed under the } \\
\text { Creative Commons } \\
\text { Attribution License. }\end{array}$} \\
\hline \multicolumn{2}{|l|}{ Read online: } \\
\hline 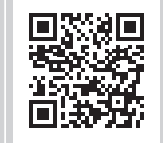 & $\begin{array}{l}\text { Scan this QR } \\
\text { code with your } \\
\text { smart phone or } \\
\text { mobile device } \\
\text { to read online. }\end{array}$ \\
\hline
\end{tabular}

Cardinal Thomas Wolsey, lord chancellor of England from 1515 to 1529, has played no small part in the many literary, historical and dramatic retellings of the reign of King Henry VIII. This article presents the first extended analysis of the way in which Wolsey has been represented by playwrights and, later, film and television writers during the years from his death in 1530 through the present. The article demonstrates that by the middle of the 16th century, two competing narratives about Wolsey had become entrenched historiographically, and nearly all subsequent accounts borrow substantially from the narratives of either Edward Hall (1550) or George Cavendish (1554-1558). How successive playwrights and screenwriters balanced the cardinal's two archetypal personae has often depended, in no small part, on the concerns of their own day. In the 21st century, readings of the cardinal as crafty rather than callous, unlucky rather than unprincipled, have become more common, and with them have come more sympathetic portrayals of a traditional Tudor villain.

\section{Introduction}

The story of Henry VIII, Anne Boleyn, and the years leading up to the English Reformation has been told countless times in the past five centuries. Dozens of historical novels, poems, plays, pamphlets and more recently films and television programmes about Henry's divorce from Katherine of Aragon have been written and produced, many of them meeting with substantial commercial and literary success. While these texts and productions have naturally focused primarily on the king and his successive queens, in the vast majority of them Cardinal Thomas Wolsey has played at least a supporting role. Wolsey, who served as lord chancellor from 1515 to 1529 and was Henry's leading counsellor during the first half of his reign, has appeared on stage and on screen in a variety of guises: as a Machiavellian political mastermind, an arrogant ecclesiastical boor and a loyal servant who ultimately fell victim, undeservingly, to Henry's (or Anne's) vindictiveness and caprice.

These conflicting accounts of Wolsey's role in the king's 'great matter', as well as of his culpability for his fall from power, have drawn in large measure upon two competing narratives about the cardinal whose main lines had been fashioned by the middle of the 16th century. According to the first narrative, Wolsey was a corrupt churchman, indeed the very epitome of late medieval excess and overreaching; either he deliberately fostered the king's scruples of conscience over his marriage for his own ends, or, out of loyalty to the pope, he deliberately blocked Henry from achieving his desires. The second narrative, in contrast, makes Wolsey out to be a harried, perhaps overproud, but certainly well-meaning administrator who sought to do Henry's bidding even as the king made increasingly impossible demands on him. Almost every serious retelling of the cardinal's role in the saga of Henry's first divorce has incorporated some elements from each of these accounts; not surprisingly, how successive playwrights and screenwriters balanced the cardinal's two archetypal personae has often depended, in no small part, on the concerns of their own day.

A few scholars have commented on stage and screen adaptations of the story of Henry VIII (Doran \& Freeman 2009; Parrill \& Robison 2013), but little work to date has been done on Wolsey's role in such productions. This essay therefore seeks to explore how Wolsey has been represented in plays, films and television programmes, beginning with portrayals of the cardinal in the months surrounding his exile and death and ending with the stage and television adaptations of Hilary Mantel's recent series of Wolf Hall novels. As we review these depictions of Cardinal Wolsey, we will discover that he has more often than not been presented as a foil to other characters in the drama of Henrician England, but when he has been depicted as a historical actor in his own right, he has inspired a broad diversity of interpretations. In the 21st century, readings of the cardinal as

Note: This essay is part of an ongoing research project on Thomas Wolsey, entitled Remembering Wolsey: The Cardinal in Literature, Historical Writing, and Drama. 
crafty rather than callous, unlucky rather than unprincipled have become more common, and with them have come more sympathetic portrayals of a traditional Tudor villain.

\section{The two Thomas Wolseys}

The contest to shape the cardinal's legacy began even before he died in disgrace at Leicester Abbey while travelling from Yorkshire to London to face trial for high treason. Not long after Wolsey's dismissal as chancellor, his successor, Thomas More, delivered an address to parliament in which he cast King Henry as a good shepherd and the cardinal as a wether, a castrated male sheep. As the London chronicler Edward Hall, about whom we will learn more shortly, recorded More's remarks:

...you se that emongest a great flocke of shepe some be rotte[n] and fauty which the good sheperd sendeth from the good shepe, so the great wether which is of late fallen as you all knowe, so craftily, so scabedly, ye \& so untruly iuggled wyth the kynge, that all men must nedes gesse and thinke that he thought him self, that the[e] had no wit to perceiue his craftie doing, or els that he presumed that the kyng woulde not se nor know his fraudulent Juggeling and attemptes: but he was deceiued, for his graces sight was so quicke and penetrable, that he saw him, ye and saw through hym, both with in and without, so that all thing to him was open, and according to his defect he hath had a gentle correction. (Hall 1550:fol. clxxxviir

The content of More's rhetoric is historically inaccurate, of course: far from the king spotting Wolsey's corruption with 'quicke and penetrable' sight, Henry had raised Wolsey to positions of authority and retained him there for more than 14 years. More is correct in that at the time he delivered his address, Henry had given Wolsey a 'gentle correction', at least comparatively: he sent him to his episcopal residence at Esher and forbade him to return to court until definitive judgement could be given. However, More is quick to caution his hearers that the king's lenient treatment of the cardinal was exceptional: 'which small ponishme[n]t the kynge will not to be an example to other offendoures, but clerly declareth that whosoeuer here after shall make like attempt or sommit like offence, shall not escape with lyke ponyshment' (fol. clxxxviir).

More's parliamentary speech was a political performance, but another attack on the cardinal's memory, this one in the guise of a dramatic production, was just around the corner. Wolsey had died in November 1530, and by early 1531 Thomas Boleyn, earl of Wiltshire, took it upon himself to stage a play mocking the cardinal. Eustace Chapuys, the emperor's ambassador to England, wrote to his master on January 23 of that year, saying that

the earl of Vulchier invited to supper Monsieur de la Guiche, for whose amusement he caused a farce to be acted of the Cardinal going down to Hell; for which La Guiche much blamed the Earl, and still more the Duke for his ordering the said farce to be printed. (Bergenroth et al. 1882:no. 615)

Chapuys wrote the words italicised here in cipher, perhaps because the Duke of Norfolk's printed version of Wiltshire's play was unauthorised; almost certainly the print run was small, and no copy appears to be extant today. ${ }^{1}$

For reasons that we will be discussing later, Wiltshire's was one of very few 16th-century dramatic presentations that featured the cardinal. While he was absent from the stage, by the middle of the century, two rival narratives about Wolsey had emerged in historical writing. The first and better known account is that first prominently set forth by Hall, the London city chronicler whose Union of the Two Noble and Illustre Families of Lancaster and York, commonly known as Hall's Chronicle, was published in 1548, with a revised edition in 1550. While Hall's Chronicle is occupied more with secular than with ecclesiastical affairs, it omits few opportunities to malign Wolsey's reputation, as I have shown elsewhere (Hornbeck 2016). ${ }^{2}$ Even before Hall first notes the public's dislike of the cardinal, he points out Wolsey's vices: pride, arrogance and an inability to tolerate rivals. According to Hall, Wolsey becomes chancellor by politicking his predecessor, Archbishop William Warham of Canterbury, out of his office. Likewise, when papal legate Cardinal Lorenzo Campeggio comes to England in 1519/20 to seek King Henry's support for a crusade against the 'Turks', Wolsey, 'whose ambicion was neuer satisfied', insists upon also being made legate before Campeggio is allowed to cross the Channel (Hall 1550:fol. lxiiiir). In the early 1520s, Hall's Wolsey squares off repeatedly with the House of Commons over royal taxation, earning the enmity of the London merchant class of which Hall was himself a member. In particular, Hall presents the so-called 'Amicable Grant' of 1525 as the nadir of Wolsey's deceit and overreaching: 'But the people toke all this for a mocke, and saied God saue the kyng, for the Cardinal is knowen wel inough, the commons would heare no prayse spoke[n] of the Cardinall, they hated hym so muche' (fol. cxliir).

Unlike several other early modern histories that are equally unsympathetic to the cardinal, Hall's narrative blames Wolsey's fall from favour not on his involvement in Henry's divorce proceedings but rather on his conduct of foreign policy. Hall's Wolsey's actions make him a potent symbol for the excessive involvement of foreign powers in English affairs. Firstly, the cardinal persuades the king to send a substantial sum of money to support the besieged Pope Clement VII, about which Hall comments that 'of this charge the realme shall not be one peny the better... [the pope] neuer shall do us good' (fol. clxiiiiv). At the same time, Wolsey is too closely identified with the French: he 'was al Frenche', and in negotiations with the French 'ye Cardinal was euer on the French part' (fols $\mathrm{clxv}^{\mathrm{r}}, \mathrm{clxxv}^{\mathrm{r}}$ ). Yet Henry's opinion of the cardinal begins to change decisively only when he is confronted with evidence that Wolsey had knowingly played him false - namely, letters that the cardinal had sent to the emperor's ambassadors in which he recommended a policy different from the king's. The king's suspicion grows when

1.On this episode, and more generally on the politics of drama during the reign of Henry VIII, see House (1995).

2.Much of the remainder of this section paraphrases my earlier analysis of Hall's and Cavendish's accounts of the cardinal. 
the legatine court investigating the legitimacy of his marriage encounters delays. Sensing an opportunity, Wolsey's longembittered enemies among the nobility present the king with a book of the cardinal's misdeeds, and ' $[w]$ hen the kyng saw the boke... he euidently perceived the high pride and couetousnes of the Cardinal, and saw openlye with what dyssymulacion and clokyng, he had ha[n]deled the Kinges causes' (fol. clxxxiiir-v). Indicted for praemunire, forced out of his home of York Place and in exile from court at his residence at Esher, the cardinal appears to accept responsibility for his actions by pleading guilty to the charges against him, but contrary to his word, he spends the remainder of his days waging a campaign of retribution and complaint. Especially once he has returned to York, Hall's Wolsey is nothing short of seditious: he

wrote to the Court of Rome and to divers other prynces letters in reproche of the kyng.... The Cardinal also woulde speake fayre to the people to wynne their heartes, and declared euer, that he was uniustlye and untruely ordered... and to gentlemen he gaue great gyftes to allure them unto him. (fol. clxxxxiiiir)

Henry orders the cardinal's arrest, yet Wolsey resists almost to the end, claiming that as a papal legate he is not subject to royal authority and that he had already been forgiven for praemunire, a crime into which he only 'by negligence fell' (fol. clxxxxiii ${ }^{r-v}$ ). Though he does eventually submit to arrest, Hall goes so far as to imply that Wolsey wilfully frustrates the king's justice by hastening his own death before he can return to London for trial (fol. clxxxxiiii ${ }^{\mathrm{v}}$ ).

Even this brief sketch of Hall's narrative of Wolsey's misdeeds highlights many of the charges that writers like Hall have throughout the centuries laid at the cardinal's feet. The story about Wolsey that these writers told was overwhelmingly negative: for them, the cardinal embodied the pomp, pride and political and financial grasping of Rome. Others, more virulent than Hall himself, added to these complaints insults and disparaging anecdotes. In the 1570 edition of John Foxe's Actes and Monuments, Wolsey's corpse 'was blacke as pitch, and also was so heauy, $\mathrm{y}^{\mathrm{t}}$ vi. could scares beare it. Furthermore, it did so stincke aboue the ground, $\mathrm{y}^{\mathrm{t}}$ they were co[n]streyned to hasten the burial therof'. To add a final insult, 'At the which burial, such a tempest, with such a stincke there arose, that all the torches went out, and so he was throwen into the tomb' (Foxe 1570:1133a). Holinshed's Chronicle mocks what its authors take to be Wolsey's conspicuous waistline, calling him 'a proud popeling; as led with the like spirit of swelling ambicion, wherewith the rable of popes had beene bladder like puffed and blowne up' (Holinshed 1587:837).

If it is fair to say that Hall and writers of his ilk constructed a narrative that foregrounded Wolsey's Roman pomposity and unrepentant treachery, a competing perspective was articulated sometime between 1554 and 1558 by George Cavendish, one of Wolsey's former gentleman-ushers. The modern editors of Cavendish's biography, Thomas Wolsey, Late Cardinall, His Lyffe and Deathe, have pointed out that the text 'stands out uniquely among 16th-century accounts of the Cardinal, for it is no exaggeration to say that both Protestant and Catholic writers of the period tend to treat Wolsey as the most despicable of men' (Sylvester \& Harding 1962:x; see also Sylvester 1960). The Life is a personal as well as a political portrait of its subject, and Cavendish's role as one of Wolsey's intimate servants afforded him a measure of access to and sympathy for the cardinal that would have been impossible for an evangelical-leaning London MP such as Hall (Anderson 1984:36-37).

Cavendish's Wolsey is not without his blemishes. Many episodes in the Life present the cardinal as ambitious, excessively concerned for pomp and ostentation, jealous of rivals, arrogant and greedy. According to Cavendish, Wolsey tempted fate (a major interpretive device in the Life) with his worldly success, and so, even if he did not deserve his end, he risked his fall by trusting too much in the stability of good fortune and in the favour of an earthly king - a king who appears in Cavendish's pages as lustful, indecisive, selfabsorbed, and at the end 'hated' by the cardinal (Cavendish 1962:193; see also Wiley 1946:126). However, unlike his counterpart in Hall, Cavendish's Wolsey responds to his fall from grace in a manner that, if not entirely humble, bears some of the marks of a spiritual conversion. The disgraced cardinal shows signs of repentance, and he adopts religious practices not previously part of his piety: on his journey north to York, he stays for some weeks at the Charterhouse at Richmond, where every day he attends prayers and where the monks 'by their counsel persuaded [him] from the vainglory of this world, and gave him divers shirts of hair, the which he often wore afterward' (133).

Once in Yorkshire, Wolsey's performance of his duties as archbishop is also, in Cavendish, framed in such a way as to reassure the king that the cardinal had learned his lesson. Plans for his installation in York Minster are 'not in so sumptuous a wise as his predecessors did before him', and en route to York Wolsey spends 2 days confirming children - the sort of quotidian pastoral duty that at the height of his power he would have found to be beneath him, and that, correspondingly, is altogether absent from Hall's narrative (148). Finally, Cavendish fashioned his account of Wolsey's death in glaring contrast to Hall's. Far from suicide, it is clear that Wolsey's final illness comes from his shock at learning that the king has sent William Kingston, constable of the Tower, to conduct him back to the capital. Wolsey's conversations with Kingston reveal him to have glimpsed the nature of the king he has served: 'rather than he will either miss or want any part of his will or appetite, he will put the loss of one half of his realm in danger'. Wolsey's famous deathbed words in Cavendish, 'if I had served God as diligently as I have done the king, he would not have given me over in my grey hairs', likewise testify to his recognition of the true state of affairs between him and Henry (Cavendish 1962:183; see Sylvester 1960:58-62; Sylvester \& Harding 1962:xii). Yet Wolsey is pensive and penitent more than he is embittered, and in Cavendish's telling his death is a good Christian one. Not unlike Christ before the crucifixion, Wolsey predicts the hour when he will die. He confesses, receives the last rites and passes away with dignity - all 
marks of the medieval ars moriendi. And when servants strip the cardinal's body for burial, they are surprised to find a shirt of hair under his fine linen (Cavendish 1962:186-187).

In contrast to Hall's arrogant and seditious Roman prelate, Cavendish's Wolsey is a more human figure: flawed, fallen but ultimately redeemed - and redeemed at least in part through stereotypically Catholic religious practices such as the wearing of a hair-shirt. While Cavendish's Life was not printed until 1641 (and even then only in a highly censored version), the text circulated in manuscript in the second half of the 16th century, and elements of Cavendish's portrayal of Wolsey appear in other, more widely distributed accounts. John Stow's Annales of England (1592) reprints many of Cavendish's narratives of Wolsey's journeys, banquets, servants and household arrangements. The authors of Holinshed's Chronicle, which as we have already seen borrows some criticisms from Hall, followed Cavendish in part for their narrative of Wolsey's fall, and William Shakespeare and John Fletcher borrowed from both Hall's and Cavendish's narratives in writing their play Henry VIII (All Is True).

It is perhaps artificial to speak of a 'Hall narrative' and a 'Cavendish narrative' about Wolsey, because few later writers borrowed only from one or the other of these authors; because Hall and Cavendish agree with each other on some points and because there was also a flourishing tradition of Catholic recusant writing about Wolsey. However, for the purposes of examining later depictions of Wolsey, it is not unhelpful to think of a continuum running between Hall's unflattering portrayal and Cavendish's sympathetic biography, a continuum on which it then becomes possible to locate individual histories, plays and video productions. It is this continuum that will structure the analysis that follows.

\section{Wolsey on the early-modern stage}

In 1526-1527, a satirical play performed at Gray's Inn aroused Wolsey's suspicions: it was, as Hall describes it, an allegory in which 'lord gouernaunce was ruled by dissipacion and negligence, by whole misgoueranance and euil order, lady Publike wele was put from gouernance: which caused Rumor Populi' (Hall 1550:fol. cliiiiv). Wolsey perceived the play to be a criticism of him and his administration, and he temporarily imprisoned the playwright, John Roo, along with one of the unnamed actors. 'Yet', Hall continues, 'it was neuer meante to hym... wherefore many wysemen grudged to see hym take it so hartely' (fol. cliiii ${ }^{v}$ ). Apart from this play and the masque of The Cardinal's Descent into Hell that, as we have already seen, was commissioned by Anne Boleyn's father, no extant dramatic production from the years on either side of Wolsey's fall appears to feature the cardinal explicitly. It is not surprising that few would depict the cardinal prior to his dismissal, because his treatment of Roo and other critics offered an object lesson concerning the price of dissent. While it is also not surprising that the Boleyns exalted in Wolsey's defeat and death, King Henry's unpredictably shifting attitudes towards his former first minister made it dangerous to impugn the cardinal's memory. Even in Cavendish's account of the days immediately following Wolsey's death, Henry's ambivalence is clear: upon meeting Cavendish, the king 'he examined me of divers weighty matters concerning my lord, wishing that lever than 20000 pounds he had lived' (Cavendish 1962:188).

It was not until the early 17th century, following the reign of Anne Boleyn's daughter Elizabeth I, that dramatic productions regularly began to feature Wolsey as a character. The first two decades of the 1600s saw the appearance of at least two major plays concerning the court of Henry VIII: Samuel Rowley's When You See Me, You Know Me in 1604 and William Shakespeare's and John Fletcher's King Henry VIII (All Is True) in 1613. The former is a historically fanciful account, one that leaves Wolsey alive through the time of the birth of the future King Edward VI and that has Henry marry Katherine Parr, rather than Anne of Cleves, upon the death of his beloved Jane Seymour. The playwright, Samuel Rowley, remains a relatively obscure figure: it is known that he acted in at least three companies of players in the closing years of the 16th century and the first two decades of the 17 th, and he may have contributed to the writing of several plays credited to either Shakespeare or Christopher Marlowe (Cerasano 2010).

Despite its manipulation of chronological time, When You See Me, You Know Me presents the main lines of the conflict between Wolsey and Henry, as Hall understood them to be. Early in the play, Wolsey is exceedingly confident of his influence over the king who gave him power: 'Great England's lord have I so won with words,/That, under colour of advising him,/I overrule both council, court, and king' (Rowley 1874:5-6). The cardinal's chief concerns in the opening half of the play are, firstly, to combat the Lutheran views that he associates with Anne Boleyn, Katherine Parr and Thomas Cranmer, and, secondly, to advance his candidacy for the papacy. He gloats over Anne's fall yet worries that Katherine 'is the hope of Luther's heresy/If she be queen, the protestants will swell,/And Cranmer, tutor to the prince of Wales,/Will boldly speak 'gainst Rome's religion' $(16,39) .^{3}$ In contrast, the Protestant point of view is advanced by an unlikely character, the king's fool Will Summers, who at one point reminds Wolsey of his unpopularity with the commons: 'If you should die,/There's none would cry,/Though your neck should break' (39, 25; see Pineas 1972; Robinson 2002). The conflict comes to a head when Wolsey and his fellow bishops attempt to arrest Queen Katherine, and in the ensuing debate, Summers reveals to Henry that he has, quite by accident, discovered the hidden extent of the cardinal's wealth (72). The king momentarily defends his minister, but then dramatically reverses course, charges Wolsey with a list of misdeeds and banishes him from court: 'Durst thou presume so, base-born cardinal,/ Without our knowledge to abuse our name? ... Belike thou meanst to level at a crown,/But thy ambitious crown shall hurl thee down' (76). The list of charges that Henry directs at the cardinal - that he placed his cardinal's hat on the royal clear that he advised the young king on theological matters (MacCulloch 1999). 
coinage, that he negotiated with foreign potentates without the king's permission, that he made himself equal to the king by using the phrase Ego et rex meus and that he seized religious properties to enrich himself - are drawn from the indictment against Wolsey that historically was presented to parliament in 1529, and all but one of the charges appear in Hall's summary of that indictment (cp. Hall 1550:fols clxxxix ${ }^{\mathrm{v}}-\mathrm{cl} x x_{x x}$; ; Rowley 1874:72-76). Likewise, Rowley's play resembles Hall's account inasmuch as it omits any mention of the cardinal experiencing repentance: here, as in Hall, Wolsey remains obstinate to the end: 'Yet will I proudly pass as cardinal,/Although this day define my heavy fall' (Rowley 1874:76).

In contrast, Shakespeare's and Fletcher's play is a more balanced, if sometimes too sharply drawn, depiction of Wolsey's career. The playwrights borrowed extensively from Tudor accounts of King Henry's reign, chief among them Holinshed's Chronicles, which itself amalgamated materials from both Hall's and Cavendish's texts (pace Cox 1978:404). Unlike most of those who went before them, and certainly unlike Rowley, Shakespeare and Fletcher craft a sharp contrast between the proud, dominant Wolsey of the first half of the play and the disgraced, penitent Wolsey of the second. Hall's Wolsey, in other words, here yields place to Cavendish's. In the first two acts, Wolsey procures the execution of the Duke of Buckingham, deceives the king about the origins of the Amicable Grant and arranges for the trial of the king's marriage. But in the third act, contrary to the cardinal's intent, the king receives a damning cache of documents that include an inventory of Wolsey's wealth, along with his letter to the pope arguing against Henry's divorce. ${ }^{4}$ Shakespeare and Fletcher imagine a vigorous confrontation between king and cardinal, after which Wolsey concedes that he had sought wealth 'For mine own ends indeed to gain the popedom' and that now his career has run its course: 'I have touched the high point of all my greatness, / And from that full meridian of my glory/I haste now to my setting' (Shakespeare \& Fletcher 2000:3.2.212, 223-225). Talking afterwards with Thomas Cromwell, Wolsey admits that 'My high-blown pride/At length broke under me and now has left me,/Weary and old with service, to the mercy/ Of a rude stream that must for ever hide $\mathrm{me}^{\prime}$ (3.2.361-364). The cardinal recognises that his way of life was sinful and unsustainable:

Mark but my fall and that that ruined me.

Cromwell, I charge thee, fling away ambition.

By that $\sin$ fell the angels. How can man then,

The image of his maker, hope to win by it?

Love thyself last; cherish those hearts that hate thee.

Corruption wins not more than honesty. (3.2.439-444)

Wolsey's last words - 'Farewell,/The hopes of court: my hopes in heaven do dwell' - mark the fullness of his conversion, and Shakespeare and Fletcher bring down the

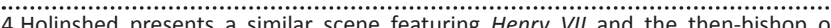
Durham, and the most recent editor of Henry VIII has noted as well a paralle between this scene and one in Foxe (Shakespeare \& Fletcher 2000:339); to these between this scene and one in Foxe (Shakespeare \& Fletcher 2000:339); to these
sources we might add Hall's account of Wolsey's deceptiveness in his correspondence (Hall 1550:fol. clxxiiir-v). curtain on the cardinal's last appearance in their play in terms reminiscent far more of Cavendish than of Hall.

Stella Fletcher (2009) has catalogued the many productions of King Henry VIII from the early 17th century through the present day, noting that the portrayal of Wolsey in Shakespeare's and Fletcher's play has often reflected the prevailing sentiments of the time. ${ }^{5}$ The play was first performed at the Globe Theatre on June 29, 1613, a date better known for the fire that burned the theatre to the ground when a cannon fired during the performance ignited the wooden structure. Later performances took place on both sides of the Commonwealth period, in 1628, 1663 and 1672 (Dreher 1981:iv). In the 18th century, Fletcher notes that the play was staged regularly, but perhaps most notably was performed in connection with the coronations of George II and George III. In the former instance, the play was produced by Colley Cibber, who earlier in his life had volunteered to take part in a regiment supporting the claims of William of Orange to the English throne. In many 17th- and 18th-century performances Wolsey was portrayed as a comic figure, a tradition that was dealt a serious blow in 1788, when John Philip Kemble, a Catholic actor-manager, 'established Wolsey as a prominent and serious part for generations of actors' (Fletcher 2009:181). Nineteenth- and twentieth-century performances and performers are too many to enumerate, but particularly significant were Charlotte Cushman's 'gender-bending precedent' in a U.S. production of 1859; Henry Irving's Wolsey of 1892, described by one reviewer as 'a cultured and crafty ascetic, not a man of dogged determination and of iron will' $(182,185)$; Herbert Beerbohm Tree's long-running Wolsey, with no fewer than 254 performances in London and 63 in New York between 1910 and 1916, in addition to a film version we will encounter shortly; and John Gielgud's surprisingly lean but crafty cardinal of a 1958 production at the Old Vic in London.

But before we turn to a series of new compositions that appeared starting in the early twentieth century, one more early modern text demands our attention. In 1682, John Banks added to the many anti-Catholic plays that had been appearing in London in reaction to the so-called 'Popish Plot' of 1678 with his own Vertue Betray'd: or, Anna Bullen. ${ }^{6}$ The play was almost instantly a dramatic and commercial success: it was printed immediately, with 14 further editions produced through the end of the 18th century (Dreher 1981:vii; Spencer 1926:735-736). While little is known about Banks personally, his play is closely aligned with the Protestant establishment of his day. In it, Wolsey is the anti-hero who schemes to bring about Anne Boleyn's downfall by fabricating allegations of adultery against her. Banks assigns as Wolsey's partner in his plotting no less notorious a figure than Elizabeth Blunt, Henry VIII's onetime mistress, who begrudges the king his infatuation with Anne. As Diane Dreher points out, the play's historical inaccuracies and its diabolical caricature of Wolsey cannot be put down to Banks' ignorance, because the 5.The following paragraph draws heavily upon chapter 7 of Fletcher.

6.For different views on the textual history of Vertue Betray'd, see Backus 1932, Bastian 1962 
publication of at least a partial version of Cavendish's Life in 1641 'made the story too familiar for that'. Instead

by combining the villainy of Wolsey with that of Thomas Cromwell and further emphasizing his degeneracy by giving him a liaison with Blunt and proud ranting speeches in which he boasts of his ability to manipulate the King, Banks made the Cardinal an evil caricature of the Catholic Church itself. (Dreher 1981:vi)

Indeed, a close examination of Banks's text reveals that he painted perhaps the most villainous Wolsey to date. Both Wolsey's own speeches and those of other characters associate the cardinal with two places of horrific repute: Rome and hell. Anne's coronation, Henry Percy announces in the play's first speech, was 'so long kept secret,/[By] our great Cardinal's Delays, and Tricks/Of Rome, which Harry has with Frowns discover'd' (Banks 1981:1, emphasis original). Wolsey demonstrates throughout the play that his allegiance is more to Rome than to England. Even in his first appearance, he expostulates against Anne, 'A Lutheran Queen upon the Throne of England!/She to lye in the Bosom of our Prince!/A Buxom King, that for a wanton Smile/Will pawn his Faith, and turn an Heretick!' (3; see also 30, 62). Plotting with Blunt, Wolsey does not hesitate to invoke the powers of the devil: 'I will retire, and leave him to your Care,/To manage him with all the Art of Woman;/And Hell, if Heaven wont, inspire your Wit/and Malice' (31). Towards the end of the play, it is the young Princess Elizabeth, whom Banks and many of his contemporaries saw as the hero of the Protestant cause, who sees the truth about Wolsey:

Child [i.e., Elizabeth]. Cause I love none so well as you -

But oh you'l never hear me what I have to say,

As long as He, that Devil there, stands by

Your Elbow.

King. Ha! what Devil?

Child. That Red Thing there.

King. Oh Child; He is no Devil, he's a Cardinal.

Child. Why does he wear that huge, long Coat then?

Unless it be to hide his Cloven Feet. (68; see also 57)

Banks's identification of Wolsey with the devil represents the dominance of Hall's narrative about the cardinal in the late 17 th century and beyond. With a few notable exceptions, it was not for at least 200 years that more sympathetic portrayals of the cardinal received widespread attention, firstly within the historical guild and, later, on the stage and (eventually) the screen.?

\section{Wolsey on screen}

Notwithstanding further productions of Shakespeare's and Fletcher's Henry VIII, a gap of several centuries separates Vertue Betray'd from the next new dramatisation of Wolsey's story. The coming of film brought with it previously unthought opportunities: in 1911, five scenes from Tree's London production of Henry VIII were filmed (Barker 1911), and 1912 saw the appearance of a new, nine-minute silent film, Cardinal

7.As Fletcher 2009 notes, the exceptions include Fiddes (1726), Brewer (1876) and Creighton (1888). My forthcoming book, Remembering Wolsey: The Cardinal in
Literature, Historical Writing, and Drama, will explore these and other depictions of the cardinal in historical scholarship.
Wolsey (Blackton \& Trimble 1912), which presents Wolsey as 'entirely admirable and Henry VIII as lecherous and predatory in his pursuit of the innocent Anne Boleyn' (Parrill \& Robison 2013:36). Hal Reid played the role of Wolsey in a production that stretched historical credibility to the limit, in which Wolsey excommunicates the king, denounces an 'altered' version of the Bible, yet survives Henry's wrath and is shown, dejected but most certainly alive, in the film's final scene. This is neither Hall's nor Cavendish's Wolsey, but instead the product of historical imagination born of sympathy towards a longmaligned figure.

Other 20th- and 21st-century portrayals of Wolsey have run the gamut from the serious to the farcical. At least 14 original plays, television series and films in which the cardinal plays a meaningful role have appeared from 1900 to the present day, and like the earlier productions we have been reviewing, they cast Wolsey in a variety of roles, from dutiful servant to political schemer, traitor and victim.

Among the earliest productions featuring the cardinal is a 1920 German silent film, Anna Boleyn, tellingly titled Deception in its 1921 American release (Lubitsch 1920). It portrays its title character sympathetically, depicting her as the victim of both King Henry's often violent advances and Queen Katherine's undisguised scorn. Not unlike many later productions, the film is casual with historical fact, casting Henry Norris, rather than Henry Percy, as Anne's first love, putting Cranmer rather than Wolsey and Campeggio in charge at the court that was to try the king's divorce, and leaving Wolsey alive through the course of Henry's and Anne's marriage. In this telling, Anne becomes queen almost against her will, and the physical violence that Henry repeatedly directs at her may reflect acclaimed filmmaker Ernst Lubitsch's views on England's behaviour towards Germany during and after World War I. In Anna Boleyn, Wolsey is a quiescent, servile figure, bringing Queen Katherine the king's request for a divorce and standing among the 'church leaders', as the caption tells us, who assemble for the annulment court. When Cardinal Campeggio arrives and reads a papal bull against the divorce, Henry destroys the bull and immediately declares himself head of the church; Wolsey, who is never explicitly presented as a cardinal, stands his ground with his fellow English bishops while Campeggio, defeated, slinks back to Rome. The final scene in which he appears has Henry begging him and other churchmen to pray that Anne might have a son.

Wolsey is equally innocuous in a 1922 silent film, When Knighthood Was in Flower (Vignola 1922), later remade, with sound, by Perce Pearce and Walt Disney as The Sword and the Rose (Disney, Pearce \& Annakin 1953). Both films adapted a turn of the century novel, When Knighthood Was in Flower, by Charles Major (1898). The protagonist of both the novel and the films is Mary Tudor, King Henry's younger sister, who falls in love with Charles Brandon, presented here as a swashbuckling newcomer to court rather than the long-time associate of Henry's that he was in life. Her feelings for Brandon notwithstanding, Henry marries Mary off to the 
elderly King Louis XII of France, and upon the French king's death, Mary schemes to return to England and wed Brandon, despite the amorous intentions of both a still-alive Duke of Buckingham and a new French king, Francis I. In The Sword and the Rose, Wolsey appears as an older man, an advisor whom the king consults separately from his other courtiers. Unlike the historical Wolsey, here the cardinal does not seek to reconcile Mary and Brandon with Henry after their unauthorised marriage.

The appearance of Robert Bolt's play A Man for All Seasons in 1960 represented a watershed for subsequent depictions of Wolsey. Performed for the first time at the Globe Theatre, later renamed the Gielgud Theatre, in London, AMan for All Seasons is a hagiographic portrayal of the life of Thomas More, the title character whose faithfulness to his conscience and religious beliefs is the play's primary subject. Bolt's play was later performed on Broadway and sparked two motion picture adaptations, one a feature film in 1966 starring Paul Scofield as More and Orson Welles as Wolsey (Zinnemann 1966), and the other a made-for-television movie in 1988, with Charlton Heston as More and an elderly John Gielgud reprising his 1958 stage appearance as the cardinal (Heston \& Heston 1988). Among Bolt's unnamed sources for his play may have been R. W. Chambers's 1935 biography of More, which,

perhaps inspired by contemporary events and personalities, maintained that Henry 'succeeded in establishing a dictatorship' even though is 'revolted the consciences of his subjects'. (Freeman 2009:35)

Though Wolsey is a comparatively minor presence in Bolt's play and its film adaptations, appearing personally in only one scene and being referred to on only a handful of other occasions, his character is drawn in a way that emphasises his realpolitik in contrast to More's humanism. Welles's Wolsey, lauded by Fletcher as 'arguably the definitive Wolsey', is obese, realistic and determined; he appears to be a man who knows what needs to happen and who has the will power to do it (Fletcher 2009:191). He criticises More for opposing his views in a recent Privy Council meeting, averring ('briskly', in the words of Bolt's stage direction), 'You're a constant regret to me, Thomas. If you could just see facts flat on, without that horrible moral squint; with just a little common sense, you could have been a statesman' (Bolt 1990:19). The 1966 film revises Bolt's scene between Wolsey and More, emphasising the 'pressure' that Wolsey is willing to bring to bear on the papacy in the form of the confiscation of church lands and resources. The 1988 adaptation, on the other hand, preserves Bolt's script nearly whole, with Gielgud's Wolsey a thinner, less obviously corrupt counterpart to Welles's. Notwithstanding the small changes they contain, both films capture well Bolt's purpose in the scene between More and Wolsey: to contrast the cardinal's tendency towards extortion with More's saintliness and commitment to upholding the dictates of his conscience.

Few if any productions after the 1966 Man for All Seasons present Wolsey as a minor character; almost all depict him as the dominant member of the early Henrician court that he was, although they vary in portraying him as more or less independent of the king. In 1969 appeared Anne of the Thousand Days, starring Richard Burton and Geneviève Bujold, with Anthony Quayle in the part of Wolsey (Wallis \& Jarrott 1969). Unlike Lubitsch's Anna Boleyn and other earlier adaptations, in Anne of the Thousand Days the struggle between Wolsey and Anne for the king's attention receives prominent billing. At Henry's bidding, Wolsey breaks off Anne's engagement to Henry Percy, an act for which she tells him he has earned her enmity, and subsequently she criticises his wealth and excessive influence in front of the king. This subplot draws primarily on Cavendish's narrative of Anne's role in Wolsey's downfall, and Quayle's portrayal of Wolsey alludes to other elements of Cavendish's biography as well, including the spiced orange that Wolsey sniffs in his chambers to protect him from odour and disease (see Cavendish 1962:24-25). When Wolsey returns from Rome on a journey that the historical cardinal never took, having failed to win a judgment in favour of the king's divorce, Anne berates him for his 'boasted promises'. Still, her victory is not complete: Henry orders the cardinal from his presence and dismisses him as chancellor, but concludes: 'I do not forgive you. I spare you for your past services'. In a subsequent scene, as Wolsey is handing the king an inventory of all his goods, Henry softens his tone, but Wolsey responds: 'No, no, Your Majesty has taken from my shoulders a load that would sink a navy'. While not couched explicitly in terms of religious repentance, Wolsey's attitude at the moment of his departure is not that of Hall's cardinal but rather that of Cavendish's. He is a pensive, dignified casualty of the king's caprice.

Two less widely known films, one serious and the other flippant, separate Anne of the Thousand Days from the 1988 remake of A Man for All Seasons. In 1971, the British series of comedic 'Carry On' films took on the story of Henry VIII, producing its Carry on Henry (Rogers \& Thomas 1971), a farce in which Wolsey arranges a marriage between Henry and the fictional Marie of Normandy, whom Henry rejects when he discovers that she constantly eats garlic. Henry takes up with another woman, Wolsey and Cromwell bumble their way through a series of confessions and retractions of adultery on the part of Marie and her suitor Roger, and in the end Henry orders Wolsey and Cromwell to be executed for treason. The last laugh comes literally on the chopping block: Henry pardons Wolsey and Cromwell, but when they learn that he intends for them to arrange yet another marriage, they choose the axe instead. Far more earnest than Carry on Henry is a 1986 biopic of William Tyndale, God's Outlaw (Bradley, Curtis \& Tew 1986), in which Willoughby Goddard plays Wolsey and Roger Rees the title character. Here, Wolsey is criticised by Henry for allowing the 'low-born priest' Tyndale to disseminate the scriptures in English. Goddard's very corpulent Wolsey appears to be unconcerned about Tyndale and is surprisingly condescending towards Henry, but later in the film he examines John Frith and Humphrey Monmouth for heresy, and the king warns another heresy defendant to beware of 'Wolsey's fires'. 
The 1990s and early 2000s saw important developments in scholarship on the English Reformation (see, e.g. Duffy 2005, originally published in 1992), and the two major television dramas about the reign of Henry VIII made since the turn of the millennium are more sympathetic to Wolsey than almost all their predecessors. Airing in four seasons from 2007 to 2010, the television series The Tudors is perhaps best known for the liberties that it takes with the historical record (Bevan et al. \& Amiel et al. 2007-2010). Among other curiosities, the series presents Charles Brandon, in reality 7 years older than the king, as Henry's contemporary and intimate friend; it leaves Wolsey's relationship with his mistress, Joan Larke, intact to the end of his life, although the historical Wolsey married Larke to George Legh in 1519; and perhaps most significantly for our purposes, it portrays Wolsey's death as a suicide, undertaken with what appears to be a rusty paring knife. However, as Sue Parrill and William B. Robison have noted, The Tudors nevertheless offers a compelling portrait of the historical cardinal: 'Sam Neill gives perhaps the series' best performance, offering the most fully realised onscreen Cardinal Wolsey yet seen - intelligent, subtle, worldly, ambitious, yet sincerely dedicated to peace, justice, and the welfare of his young royal protégé' (Parrill \& Robison 2013:249).

Wolsey features in all 10 episodes of the series' first season, and while there is not time to review the import of each of his appearances, a few deserve particular attention. Contrary to Shakespeare's and Fletcher's account, in The Tudors Wolsey is not the cause of the Duke of Buckingham's fall; in fact, Neill's Wolsey advises Henry against the duke's execution. However, this Wolsey is also utterly realistic about his role at King Henry's court, advising Thomas More that 'if you want to keep the love of a prince, you must be prepared to give him the thing you care for most in all the world'. For Wolsey, that thing was Hampton Court, which he presents to the king at the end of the episode. Wolsey here is calm, courtly, yet not above acts of aggression when they suit his purposes - he manhandles Cardinal Campeggio's servant and then the cardinal himself, and he coldly sends the king's secretary Richard Pace to the Tower on a trumped-up charge of treason. For Neill's Wolsey, the world of politics demands ruthlessness, and he criticises his soon-to-be successor More in words that echo his counterpart in Robert Bolt's play: 'You don't want to get your hands dirty. But you have no choice'.

It is with regard to Wolsey's disgrace and fall that the The Tudors deviates most from historical fact and, simultaneously, presents the most sympathetic portrait to date of his character. After Cardinal Campeggio prorogues the legatine court, Wolsey rebukes him, and the two cardinals travel together to Grafton House to meet the king. Henry behaves kindly towards Wolsey, but the following morning, when the king and his minister had set aside time to speak further, Henry rides off with Anne while guards restrain Wolsey from following after them. The dukes of Norfolk and Suffolk take the Great Seal away from Wolsey (in this telling, unlike many others, including Cavendish's, they come prepared with the proper warrant), and Wolsey is jeered upon leaving court for the final time. The cardinal writes a letter to beg for help from his onetime servant Cromwell, but Cromwell tears it up. In the finale, even as Henry appears to be preparing to restore Wolsey to power, the cardinal, as in Hall, schemes against the king with the pope, emperor and Queen Katherine. Cromwell advises Henry of the cardinal's treachery, and Henry sends Brandon to arrest him and bring him to trial. The details of Wolsey's arrest are utterly different from Cavendish's account, although the emotional force is much the same. Here, Wolsey is arrested in the middle of the night, with Joan Larke lying next to him in their bed, and roughly hauled off in chains. A few minutes later, we see Wolsey, seemingly healthy, in prison, where after praying to God for the first time in the series, he slits his throat. The lines that writer Michael Hirst assigns Wolsey in the moments before his death - far different from Cavendish's Wolsey's musings about the service he gave to God and the king - capture the human portrayal that the series affords the cardinal:

Lord, we have not spoken as long or as often as we should. I've often been about other business. If I wanted forgiveness I should ask for it, but for all that I have done, and for all I am yet to do, there can be no forgiveness. And yet I think I'm not an evil man. Evil men pray louder and seek penance and think themselves closer to heaven than I am.... I know myself for what I am, and I throw my poor soul upon your forgiveness, in the full knowledge that I deserve none at your loving hands.

While Neill's Wolsey commits suicide, he also appears to be genuinely repentant. In the final analysis, this Wolsey is closer to Cavendish's than to Hall's, although he does not explicitly come to recognise the king as the cause of his misfortune.

If The Tudors marked the first time that Wolsey has appeared on screen as a whole person, it was by no means the last. In 2013, the Royal Shakespeare Company began to perform a two-part stage dramatisation of Hilary Mantel's Wolf Hall novels (see Mantel 2010), which re-imagine Henry's reign through the eyes of Thomas Cromwell. The productions transferred to London's Aldwych Theatre in 2014 and then to Broadway later the same year. Almost simultaneously, the British Broadcasting Corporation released a six-episode television version of the novel, with Jonathan Pryce playing the part of Wolsey. Both productions follow Mantel's novel, and therefore each other, quite closely. The television version opens with the dukes of Norfolk and Suffolk arriving at York Place to take from the cardinal the Great Seal of England. Pryce's Wolsey is in many ways the obverse of Welles's - of moderate build rather than obese, spry rather than downtrodden, kindly rather than threatening. He repeatedly offers hospitality to the dukes who come to depose him but informs them, at Cromwell's suggestion, that he cannot deliver the Seal to them unless they can produce a written warrant from the king. When Wolsey's dismissal is later officially brought to pass, he expresses to Cromwell, Cavendish and the other members of his household staff gratitude rather than bitterness towards Henry. And as the story develops in the first two episodes of the series, it becomes evident that Pryce's Wolsey, like Sam Neill's before 
him, had argued strenuously against the king's divorce, yet also dutifully, if unsuccessfully, attempted to achieve Henry's will. As in Cavendish's account, blame for Wolsey's downfall here rests primarily on the shoulders of Anne Boleyn, who first begrudges the cardinal her broken engagement to Henry Percy and then channels the anger of her father, her uncle and other noblemen towards a man whom Percy's father repeatedly calls 'butcher's dog'. The Wolsey of Wolf Hall is, therefore, highly indebted to the Wolsey of Cavendish, but Mantel goes beyond Cavendish in her ascription of motives to Cromwell. Far from the opportunistic, self-centred climber of Anne of the Thousand Days or The Tudors, this Cromwell is a devoted servant of his fallen master's. Indeed, after Wolsey's death Cromwell is incensed when the play about the cardinal's descent into hell is performed. Cavendish, recounting Wolsey's last moments, wishes that 'I knelt by his body, and I prayed to God to send vengeance upon them all'. Cromwell answers: 'There's no need to trouble God, George. I'll take it in hand'. He spends much of the remainder of the series exacting retribution on Wolsey's enemies, especially on the young noblemen who acted in the play and who come to figure centrally in the accusations of adultery that Cromwell fabricates against Anne. In the end, with their executions and the queen's, Cromwell achieves what Wolsey could not - and what Pryce's Wolsey, perhaps, may not have wanted.

\section{Conclusion}

Each of the portrayals of Thomas Wolsey that this essay has been exploring was shaped by its own peculiar constellation of circumstances: the political and ecclesial alignments of its day, the theological ideas that it sought either to evoke or to reject, the influence of other works of prose literature, poetry, stagecraft, and screenwriting. It is not unhelpful, however, to observe that with a very few exceptions, the plays, films, and television programmes we have analysed all fall at some point along the spectrum of opinion about the cardinal established in the mid-16th century with the contrasting accounts of Hall and Cavendish. To the extent that Wolsey has been seen as a villain - whether the deceptive schemer of Vertue Betray'd or the complacent, rotund ecclesiastic of God's Outlaw - motifs that have their origins in Hall are often in evidence. Likewise, to the extent that Wolsey has been depicted sympathetically, particularly in the past two decades, elements from Cavendish's Life, such as the cardinal's repentance near the time of his death, have often been on display.

When Cardinal Wolsey has appeared on stage or screen, it has rarely been for his own sake. Far more often, the cardinal has been called upon to play a role in the broader drama of the divorce of King Henry from Katherine of Aragon, and as a result, the actors who have portrayed Wolsey have found themselves serving as foils in one or another writer's telling of the divorce and the subsequent events of the English Reformation. In the early modern period, Wolsey most commonly represented the Roman church, its excesses and its corruption: When You See Me, You Know Me and Vertue Betray'd both identify him strongly with Rome over against England, and even Shakespeare's and Fletcher's Henry VIII makes him ambitious for the papal throne. In the 20th and 21st centuries, when comment on the behaviour of a recently dead English monarch has been less dangerous for those who would venture it, actors playing Wolsey have regularly delivered performances that complement, whether by similarity or contrast, the personality of the King Henry opposite them. Where Henry has been a dominant, violent character, as in Lubitsch's Anna Boleyn, Wolsey has faded into the background; where Henry has been a tyrant, as in A Man for All Seasons, Wolsey has been his compliant enforcer.

It has only been in the past two decades that Wolsey has routinely been played as a complex character in his own right. With the exception of Shakespeare's and Fletcher's Henry VIII, almost all the previous portrayals of the cardinal have tended to fall close to one end or the other of the HallCavendish spectrum, usually nearer the former than the latter. Recent scholarly works on the state of late medieval English Catholicism, on the reign of Henry VIII and the origins of the English Reformation, and on Wolsey himself, combined with a postmodern penchant to learn more about the stories of those who have historically been portrayed as villains, have leavened the ways in which writers and actors have approached Catholic England's last cardinal and lord chancellor. Recent works have pushed portrayals of Wolsey closer to Cavendish and further from Hall, but whether this is a long-term trend remains to be seen. What is all but certain is that popular enthusiasm for the story of Wolsey, Henry VIII and the Henrician court remains no less strong today than it did in early modern times.

\section{Acknowledgements Competing interests}

The author declares that he has no financial or personal relationships which may have inappropriately influenced him in writing this article.

\section{References}

Anderson, J., 1984, Biographical truth: The representation of historical persons in Tudor-Stuart writing, Yale University Press, New Haven, CT.

Backus, E.N., 1932, 'The MS. Play, “Anna Bullen”', PMLA 47, 741-752. http://dx.doi. org/10.2307/457949

Banks, J., 1981, Vertue Betray'd: Or, Anna Bullen, repr. William Andrews Clark Memorial Library, Los Angeles, CA.

Barker, W.G.B., 1911, Henry VIII, Barker Motion Photography, United Kingdom.

Bastian, J.M., 1962, 'James Ralph's second adaptation from John Banks', Huntingdon Library Quarterly 25(3), 181-188. http://dx.doi.org/10.2307/3816116

Bergenroth, G.A., De Gayangos, D.P., et al. (eds.), 1882, Calendar of letters, dispatches, and state papers, relating to the negotiations between England and Spain..., vol. 4.2, Longman, Green, Reader, and Dyer, London.

Bevan, T., et al. (Producers) \& Amiel, J., et al. (Directors), 2007-2010, The Tudors, Ireland and Canada, Showtime.

Blackton, J.S. \& Trimble, L. (Directors), 1912, Cardinal Wolsey, Vitagraph, USA.

Bolt, R., 1990, A man for all seasons, Vintage Books, New York.

Bradley, G., Curtis, K. (Producers) \& Tew, T. (Director), 1986, God's Outlaw, Bible Society/CTVC/Channel 4, United Kingdom.

Brewer, J.S., 1876, Letters and papers, foreign and domestic, of the reign of Henry VIII, vol. 4, Her Majesty's Stationery Office, London.

Cavendish, G., 1962, in R.S. Sylvester \& D.P. Harding, D.P. (eds.), 1962, Two early Tudor lives, pp. 1-193, Yale University Press, New Haven, CT. 
Cerasano, S.P., 2010, 'Rowley, Samuel (d. 1624)', in Oxford Dictionary of nationa biography, viewed 12 September 2015, from http://www.oxforddnb.com/view/ biography, viewe
article/24226

Cox, J.D., 1978, 'Henry VIII and the Masque', ELH 45, 390-409. http://dx.doi. org/10.2307/2872644

Creighton, M., 1888, Cardinal Wolsey, Macmillan, London.

Disney, W., Pearce, P. (Producers) \& Annakin, K. (Director), 1953, The sword and the rose, Disney/RKO, USA.

Doran, S. \& Freeman, T., 2009, Tudors and Stuarts on film, Palgrave, Basingstoke.

Dreher, D., 1981, Introduction to Banks, J., 1981, Vertue Betray'd: Or, Anna Bullen, repr. William Andrews Clark Memorial Library, Los Angeles, CA.

Duffy, E., 2005, The stripping of the altars, 2nd edn., Yale University Press, New Haven, CT. Fiddes, R., 1726, The life of Cardinal Wolsey, J. Knapton, et al., London.

Fletcher, S., 2009, Cardinal Wolsey: A life in Renaissance Europe, Continuum, London.

Foxe, J., 1570, The ... ecclesiasticall history ... contaynyng the actes and monuments, John Day, London.

Freeman, T., 2009, 'A tyrant for all seasons: Henry VIII on film', in S. Doran \& T. Freeman, Tudors and Stuarts on film, pp. 30-45, Palgrave, Basingstoke.

Hall, E., 1550, Union of the two noble and illustre families of Lancaster and York, Grafton, London.

Heston, F. (Producer) \& Heston, C. (Director), 1988, A man for all seasons, TV Agamemnon, USA.

Holinshed, R., 1587, The first and second volumes of chronicles, Harison, London.

Hornbeck, J.P. II, 2016, 'The Conversion of the Cardinal? Pride and penitence in some Tudor histories of Thomas Wolsey', HTS Theological Studies 72:1, 1-10.

House, S.B., 1995, 'Literature, drama, and politics', in D. MacCulloch (ed.), The reign of Henry VIII: Politics, policy, and piety, pp. 181-201, St. Martin's Press, New York.

Lubitsch, E. (Director), 1920, Anna Boleyn [motion picture], Friedrich-WilhelmMurnau-Stiftung, Germany.
MacCulloch, D., 1999, Tudor church militant, Allen Lane, London.

Major, C. [Caskoden, E.], 1898, When knighthood was in flower, Bowen-Merrill, Indianapolis, IN.

Mantel, H., 2010, Wolf Hall, Picador, London.

Parrill, S. \& Robison, W.B., 2013, The Tudors on film and television, McFarland and Company, Jefferson, NC.

Pineas, R., 1972, Tudor and early Stuart anti-Catholic drama, B. De Graaf, Nieuwkoop.

Robinson, M.S., 2002, Writing the reformation: Actes and monuments and the Jacobean history play, Ashgate, Aldershot.

Rogers, P. (Producer) \& Thomas, G. (Director), 1971, Carry on Henry, Rank/ITV Global, United Kingdom.

Rowley, S., 1874, When you see me, you know me, K. Elze (ed.), Emil Barth, Dessau.

Shakespeare, W. \& Fletcher, J., 2000, King Henry VIII, G. McMullan (ed.), Arden Shakespeare, London.

Spencer, H., 1926, 'Improving Shakespeare: Some bibliographical notes on the restoration adaptations', PMLA 41(3), 727-746. http://dx.doi.org/10.2307/457624

Stow, J., 1592, The annales of England, Newbery, London.

Sylvester R.S., 1960, 'Cavendish's Life of Wolsey: The artistry of a Tudor biographer', Studies in Philology 57, 44-71.

Sylvester, R.S. \& Harding, D.P. (eds.), 1962, Two early Tudor lives, Yale University Press, New Haven, CT.

Vignola, R.G. (Director), 1922, When knighthood was in flower [motion picture], Cosmopolitan/Paramount, USA.

Wallis, H. (Producer) \& Jarrott, C. (Director), 1969, Anne of the Thousand Days, Hal Wallis Productions, United Kingdom.

Wiley, P., 1946, 'Renaissance exploitation of Cavendish's Life of Wolsey', Studies in Philology 43, 121-146.

Zinnemann, F. (Producer and Director), 1966, A man for all seasons, Highland/ Columbia, United Kingdom. 